\title{
Pengintegrasian TPACK dalam Pembelajaran Transformasi Geometri SMA untuk Mengembangkan Profesionalitas Guru Matematika
}

\author{
Ibnu Rafi * \\ Program Studi Pendidikan Matematika, Universitas Negeri Yogyakarta, Yogyakarta, Indonesia \\ *Penulis Korespondensi, ibnurafi789@gmail.com \\ Nurrita Sabrina \\ Program Studi Pendidikan Matematika, Universitas Negeri Yogyakarta, Yogyakarta, Indonesia \\ momo.aina25@gmail.com
}

\begin{tabular}{|c|c|}
\hline Informasi Artikel & ABSTRAK \\
\hline $\begin{array}{l}\text { Sejarah artikel: } \\
\text { Diterima } 29 \text { Agustus } 2018 \\
\text { Direvisi } 18 \text { November } 2018 \\
\text { Disetujui } 26 \text { November } 2018\end{array}$ & $\begin{array}{l}\text { Artikel ini membahas mengenai cara pengintegrasian kerangka } \\
\text { Technological, Pedagogical and Content Knowledge (TPACK) } \\
\text { dalam pembelajaran transformasi geometri SMA untuk } \\
\text { mengembangkan profesionalitas guru matematika. Artikel ini } \\
\text { merupakan hasil kajian pustaka dengan sumber kajian berupa artikel } \\
\text { jurnal, undang-undang dan laman web yang bertemakan TPACK, Uji }\end{array}$ \\
\hline $\begin{array}{l}\text { Kata kunci: } \\
\text { Profesionalitas guru, TPACK, } \\
\text { transformasi geometri SMA, } \\
\text { workshop penggunaan } \\
\text { GeoGebra }\end{array}$ & $\begin{array}{l}\text { Kompetensi Guru (UKG), profesionalitas guru, dan penggunaan } \\
\text { GeoGebra dalam pembelajaran. Penulisan artikel ini dilatarbelakangi } \\
\text { oleh capaian rata-rata Uji Kompetensi Guru (UKG) pada bidang studi } \\
\text { matematika yang mengindikasikan perlu adanya pengembangan } \\
\text { profesionalitas guru matematika, terutama pada kompetensi } \\
\text { pedagogik dan profesional. Salah satu kerangka yang memfasilitasi } \\
\text { pengembangan dua kompetensi tersebut adalah Technological, } \\
\text { Pedagogical and Content Knowledge (TPACK). Melalui TPACK, } \\
\text { guru matematika diharapkan dapat mengintegrasikan teknologi dalam } \\
\text { pembelajaran pada materi matematika yang bersifat abstrak, seperti } \\
\text { transformasi geometri. Berdasarkan hasil kajian, pengintegrasian } \\
\text { TPACK dapat mengembangkan profesionalitas guru matematika } \\
\text { melalui kegiatan workshop penggunaan GeoGebra dalam } \\
\text { pembelajaran transformasi geometri SMA. }\end{array}$ \\
\hline & $\begin{array}{l}\text { Copyright } \odot 2019 \text { by the authors; licensee Department of Mathematics Education, } \\
\text { University of Singaperbangsa Karawang. All rights reserved. } \\
\text { This is an open access article distributed under the terms of the CC BY-SA license. } \\
\text { (http://creativecommons.org/licenses/by-sa/4.0) }\end{array}$ \\
\hline
\end{tabular}

\section{PENDAHULUAN}

Dewasa ini teknologi tengah berkembang pesat dan dapat dijumpai diberbagai sektor kehidupan salah satunya sektor pendidikan. Pendidikan merupakan salah satu investasi terbesar terlebih lagi untuk mempersiapkan keterampilan pada abad 21 yang tengah digencarkan sekarang ini. Keterampilan abad 21 yakni berpikir kreatif dan inovatif, pemecahan masalah dan berpikir kritis, komunikasi dan kolaborasi dapat diwujudkan dalam pembelajaran matematika. Untuk mencapai tujuan tersebut diperlukan peran pendidik dalam perancangan kegiatan pembelajaran matematika. Ariani (2015) menyatakan bahwa seorang guru matematika harus mampu menciptakan kegiatan pembelajaran yang aktif, kreatif, menyenangkan dan bermakna dengan memerhatikan cakupan materi dan keterkaitannya dengan materi lain, strategi dan media pembelajaran yang digunakan serta latar belakang kemampuan matematika peserta didik sebelumnya. 
Hal ini juga dijelaskan dalam Undang-undang Republik Indonesia Nomor 14 Tahun 2005 tentang Guru dan Dosen bahwa seorang guru harus memiliki empat kompetensi yaitu kompetensi pedagogik, kepribadian, sosial dan profesional. Kompetensi pedagogik dipandang sebagai kemampuan guru dalam mengelola pembelajaran. Kompetensi kepribadian mencerminkan kemampuan personal yang berwibawa dan berkarakter sebagai guru. Selanjutnya kompetensi sosial dipandang sebagai kemampuan guru dalam berinteraksi dengan peserta didik, wali peserta didik, guru ataupun tenaga kependidikan lainnya, serta masyarakat sekitar. Sedangkan kompetensi profesional dipandang sebagai kemampuan dalam menguasai materi, implementasinya, serta penguasaan ilmu pengetahuan, teknologi, seni ataupun budaya. Jadi dapat disimpulkan bahwa dalam perancangan kegiatan pembelajaran seorang guru diharapkan memperhatiakan materi, strategi, teknologi ataupun kebudayaan sekitar dalam membantu mewujudkan pembelajaran yang aktif, kreatif, menyenangkan dan bermakna.

Profesionalitas kinerja guru untuk mewujudkan kegiatan pembelajaran matematika yang aktif, kreatif, menyenangkan dan bermakna sangat ditekankan oleh pemerintah. Oleh karena itu setiap tahunnya pemerintah selalu menyelenggarakan Uji Kompetensi Guru (UKG) dan penilaian kinerja guru untuk menilai dan meningkatkan kompetensi guru (Ariani, 2015). Menurut Peraturan Menteri Pendidikan dan Kebudayaan Republik Indonesia Nomor 57 Tahun 2012 tentang Uji Kompetensi Guru, UKG merupakan pengujian terhadap penguasaan kompetensi profesional dan pedagogik dalam ranah kognitif sebagai dasar penetapan pengembangan keprofesian berkelanjutan dan juga penilaian kerja guru. Ariani (2015) menyatakan bahwa kompetensi yang diujikan pada UKG adalah $70 \%$ kompetensi profesionalitas dan 30\% kompetensi pedagogik. Artinya profesionalitas guru dapat dilihat dengan ketercapaian nilai UKG. Untuk bidang studi matematika capaian rata-rata UKG yang diikuti oleh 76.881 guru dari jenjang SMP, SMA, dan SMK adalah 50,86. Sebanyak 48\% guru mendapatkan nilai dibawah rata-rata, 23\% mendapatkan nilai diantara 50 dan 60 serta sisanya mendapatkan nilai di atas 60 (Purnama, 2015). Jika dilihat hampir setengah dari peserta yang mengikuti UKG mendapatkan nilai capaian dibawah rata-rata. Hal ini mengindikasikan bahwa nilai profesionalitas guru matematika dalam memanfaatkan teknologi, seni dan budaya sesuai dengan kompetensi profesionalitas untuk menciptakan pembelajaran yang aktif, kreatif, menyenangkan dan bermakna masih perlu untuk ditingkatkan. Sehingga, perlu adanya kerangka berpikir yang dapat memfasilitasi kompetensi guru khususnya kompetensi pedagogik dan profesional. Salah satu kerangka yang memfasilitasi kompetensi tersebut adalah Technological, Pedagogical and Content Knowledge (TPACK).

Dengan adanya kerangka berpikir TPACK ini, guru diharapkan dapat memanfaatkan teknologi sebagai media pembantu dalam memfasilitas siswa untuk memahami suatu konten pembelajaran - terutama untuk konten matematika yang bersifat abstrak-dan tentunya tetap mempertimbangkan aspek pedagogis. Doering, Veletsianos, Scharber, \& Miller (2009) dalam penelitiannya menyatakan bahwa penginterasian TPACK mampu meningkatkan kepercayaan diri serta peningkatan kompetensi konten, pedagogis dan teknologi guru dalam mendesain pembelajaran. Selanjutnya, Listiawan \& Baskoro (2015) melakukan analisis terhadap kemampuan guru yang bertujuan untuk mengetahui sejauh mana guru dapat mempresentasikan materi matematika khususnya geometri sesuai dengan kerangka TPACK. Hal tersebut dilatarbelakangi dari penggunaan perangkat lunak (software) dalam pembelajaran geometri berdampak positif terhadap prestasi peserta didik dikarenakan titik, garis, dan bidang dapat direpresentasikan dengan mudah. Dari uraian sebelunya dapat disimpulkan bahwa pengintegrasian TPACK memberikan dampak yang positif untuk guru dan peserta didik. Makalah ini akan mengkaji tentang peng-integrasian 
TPACK untuk mengembangkan profesionalitas guru dalam pembelajaran matematika khususnya materi transformasi geometri SMA berbantuan software GeoGebra.

\section{METODE}

Artikel ini merupakan hasil kajian pustaka. Sumber-sumber kajian yang digunakan meliputi artikel jurnal nasional dan internasional, undang-undang (atau peraturan menteri/ pemerintah), dan artikel website yang berkaitan dengan tema, dan : (a) profesionalitas guru (matematika); (b) Uji Kompetensi Guru (UKG); (c) pengintegrasian Technological, Pedagogical and Content Knowledge (TPACK) dalam pembelajaran (matematika); dan (d) penggunaan software GeoGebra dalam pembelajaran geometri. Adapun kata kunci yang digunakan untuk mendapatkan sumber kajian adalah 'TPACK.pdf', 'TPACK dalam pembelajaran matematika.pdf', 'integrating geogebra with TPACK.pdf', 'profesionalitas guru.pdf', 'penggunaan Geogebra dalam pembelajaran matematika.pdf', dan 'uji kompetensi guru (UKG),

\section{HASIL DAN PEMBAHASAN}

\section{Profesionalitas Guru}

Sebelum membahas mengenai profesionalitas guru, terlebih dahulu dibahas mengenai pengertian profesi, profesional dan profesionalitas. Profesi dapat dipahami sebagai jenis pekerjaan yang khas yang memerlukan pengetahuan (Ridla, 2008) dan untuk melaksanakan perkerjaan tersebut perlu landasan pendidikan keahlian, keterampilan, atau kejuruan (Sururi, 2002). Orang yang menyandang profesi tersebut atau penampilan seseorang dalam melakukan pekerjaan yang sesuai profesinya disebut sebagai profesional. Adapun yang dimaksud dengan profesionalitas adalah sikap profesional terhadap profesinya atau tingkat pengetahuan dan keterampilan yang dimiliki oleh profesional dalam melaksanakan profesinya (Sururi, 2002). Apabila dikaitkan dengan tugas guru yang sebagaimana tertulis dalam Undang-undang Republik Indonesia Nomor 14 Tahun 2005 tentang Guru dan Dosen pasal 1 ayat (1), yaitu mendidik; mengajar; membimbing; mengarahkan; melatih; menilai; dan mengevaluasi peserta didik pada pendidikan anak usia dini jalur pendidikan formal, pendidikan dasar, dan pendidikan menengah, maka yang dapat dipahami bahwa yang dimaksud dengan profesionalitas guru adalah sikap atau tingkat pengetahuan, keahlian, dan kompetensi seorang guru dalam melaksanakan tugasnya.

Guru sebagai pendidik profesional tentunya diharapkan dapat menguasai empat kompetensi yang meliputi kompetensi pedagogik, kompetensi kepribadian, kompetensi sosial, dan kompetensi profesional. Berdasarkan Undang-undang Republik Indonesia Nomor 14 Tahun 2005 tentang Guru dan Dosen, pasal 10 ayat (1), kompetensi pedagogik adalah kemampuan dalam mengelola peserta didik dan proses pembelajaran di kelas; kompetensi kepribadian adalah kemampuan guru untuk bersikap dan berakhlak yang baik serta menjadi contoh bagi peserta didik; kompetensi sosial adalah kemampuan guru dalam berkomunikasi dan berinteraksi dengan warga sekolah dan masyarakat; dan kompetensi profesional adalah kemampuan dalam menguasai materi pembelajaran. Keempat kompetensi tersebut perlu untuk terus dikembangkan agar profesionalitas guru dalam memfasilitas peserta didik untuk belajar dapat berkembang pula. Dengan berkembangnya profesionalitasnya, guru tersebut dapat menjadi guru yang bermutu. Guru yang bermutu adalah guru yang menguasai keempat kompetensi guru dan profesionalitas dalam memfasilitasi peserta didiknya untuk belajar (Ridla, 2008). 
Pemerintah selalu berupaya untuk memonitor profesionalitas guru di seluruh Indonesia melalui pengadaan Uji Kompetensi Guru (UKG). UKG ini terfokus pada evaluasi terhadap kompetensi pedagogik dan kompetensi profesional dalam ranah kognitif (lihat Tabel 1).

Tabel 1. Kompetensi Pedagogik dan Kompetensi Profesional Guru yang Diuji pada UKG

\begin{tabular}{|c|c|}
\hline Jenis Kompetensi & Deskripsi/Penjelasan \\
\hline Kompetensi Pedagogik & $\begin{array}{ll}\text { - } & \text { Mengenal karakteristik dan potensi peserta didik } \\
\text { - } & \text { Menguasai teori belajar dan prinsip-prinsip pembelajaran yang efektif } \\
\text { - } & \text { Menguasai perencanaan dan pengembangan kurikulum } \\
\text { - } & \text { Menguasai langkah-langkah pembelajaran yang efektif } \\
\text { - } & \text { Menguasai sistem, mekanisme, dan prosedur penilaian } \\
\end{array}$ \\
\hline Kompetensi Profesional & $\begin{array}{l}\text { - Menguasai materi, struktur, konsep, dan pola pikir keilmuan yang } \\
\text { mendukung mata pelajaran yang diampu guru } \\
\text { - } \text { Menguasai metodologi keilmuan sesuai bidang tugas yang dibebankan } \\
\text { kepada guru } \\
\text { - } \text { Menguasai hakikat profesi guru }\end{array}$ \\
\hline
\end{tabular}

(Sumber: Peraturan Menteri Pendidikan dan Kebudayaan Republik Indonesia Nomor 57 Tahun 2012 tentang Uji Kompetensi Guru)

Berbagai usaha dapat dilakukan untuk mengembangan profesionalitas guru. Profesionalitas guru dapat dikembangkan melalui pengadaan forum Musyawarah Guru Mata Pelajaran (MGMP), seminar atau workshop, penerbitan majalah ilmiah, lesson study, pelatihan, dan studi lanjut (Marsigit, 2008). Usaha atau kegiatan pengembangan profesionalitas guru tentunya diharapkan dapat berlangsung secara berkelanjutan dan periodik sedemikian sehingga setidaknya dua dari empat kompetensi guru, yaitu kompetensi pedagogik dan kompetensi profesional dapat berkembang. Artikel ini terfokus pada pengembangan profesionalitas guru melalui kegiatan workshop yang mengintegrasikan TPACK dan penggunaan GeoGebra dalam pembelajaran transformasi geometri SMA.

\section{Pengintegrasian TPACK dalam Pembelajaran}

Technological, pedagogical and content knowledge (TPACK) merupakan kerangka kerja mengenai pengetahuan-pengetahuan yang diperlukan oleh guru untuk mengintegrasikan teknologi dalam pembelajaran secara efektif (Koehler, Mishra, \& Cain, 2013; Mishra \& Koehler, 2008). Pengetahuan-pengetahuan yang dimaksud di sini adalah technological knowledge (TK) — pengetahuan dalam memanfaatkan teknologi, pedagogical knowledge (PK) - pengetahuan dalam mengelola peserta didik dan pembelajaran di kelas, content knowledge (CK) - pengetahuan terhadap materi yang dipelajari atau diajarkan kepada peserta didik, serta pengetahuan terhadap keterkaitan antara tiga pengetahuan yang pertama dalam memfasilitas peserta didik untuk belajar (lihat Gambar 1). Lebih lanjut, Koehler et al (2013) dan Mishra \& Koehler (2008) mengemukakan bahwa pemahaman terhadap TK, PK, CK, dan hubungan antara ketiga pengetahuan-Technological Pedagogical Knowledge (TPK), Technological Content Knowledge (TCK) dan Pedagogical Content Knowledge (PCK) — ini meliputi pemahaman terhadap: (a) cara menyajikan suatu konsep dengan menggunakan teknologi-teknologi pembelajaran yang ada; (b) teknik pedagogis yang digunakan untuk membelajarkan suatu materi dengan menggunakan teknologi secara konstruktif; (c) penyebab suatu konsep sulit atau mudah untuk dipelajari dan bagaimana teknologi dapat membantu peserta didik dalam mempelajari dan memahami konsep tersebut; (d) pengetahuan awal peserta didik; dan (e) cara mengaktifkan pengetahuan awal peserta didik dengan memanfaatkan teknologi untuk 
membangun pengetahuan yang baru atau memperkuat pengetahuan yang lama dengan memanfaatkan teknologi.

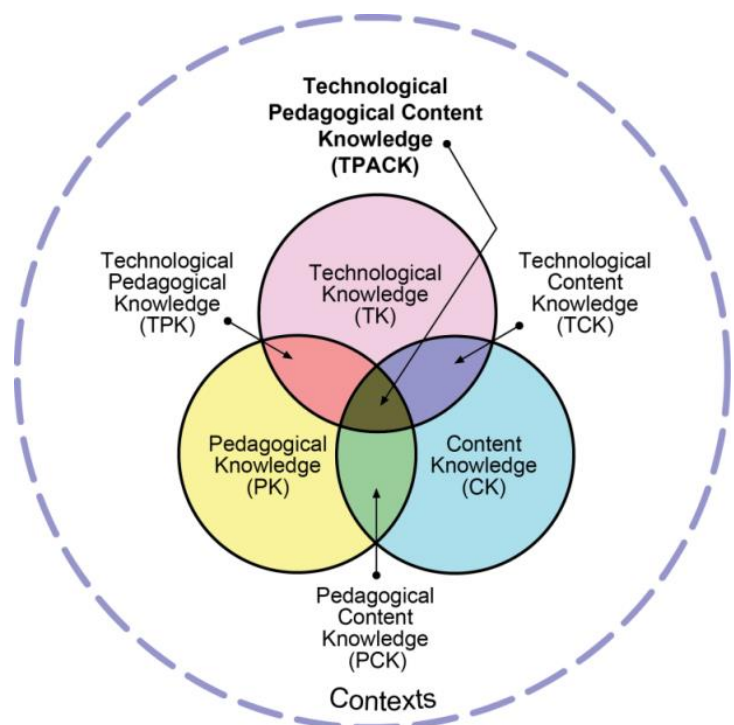

Gambar 1. Komponen TPACK (Sumber: http://www.tpack.org/)

Sebelum dibahas mengenai pengintegrasian TPACK dalam pembelajaran, terlebih dahulu dijelaskan mengenai TK, PK, CK, TPK, TCK, dan PCK sebagai komponen TPACK (lihat Tabel 2).

Tabel 2. Penjelasan mengenai TK, PK, CK, TPK, TCK, dan PCK sebagai Komponen TPACK

Jenis Pengetahuan
Deskripsi/Penjelasan

Technological Knowledge - Pengetahuan tentang teknologi, mulai dari teknologi yang bersifat low-tech (TK)

\section{software)}

- Pengetahuan yang mencakup keterampilan-keterampilan yang diperlukan untuk mengoperasikan teknologi tertentu

- Pemahaman terhadap penggunaan teknologi informasi untuk membantu dalam mencapai tujuan, berkomunikasi dan memecahkan masalah atau menyelesaikan tugas tertentu

\begin{tabular}{|c|c|}
\hline $\begin{array}{l}\text { Pedagogical } \\
\text { (PK) }\end{array}$ & $\begin{array}{l}\text { - Pengetahuan mengenai proses dan pelaksanaan atau metode pembelajaran } \\
\text { - Pemahaman terhadap cara peserta didik belajar, keterampilan dalam } \\
\text { memanajemen kelas, pe-rencanaan pembelajaran, dan strategi untuk me- } \\
\text { nilai peserta didik }\end{array}$ \\
\hline Knowledge & $\begin{array}{l}\text { Pengetahuan dan pemahaman terhadap materi yang dipelajari atau diajarkan } \\
\text { kepada peserta didik yang meliputi fakta; konsep; teori; dan prosedur }\end{array}$ \\
\hline $\begin{array}{l}\text { Technological } \\
\text { Pedagogical Knowledge } \\
\text { (TPK) }\end{array}$ & $\begin{array}{l}\text { Pemahaman terhadap perubahan cara dan proses pembelajaran sebagai } \\
\text { akibat dari penggunaan teknologi dalam pembelajaran }\end{array}$ \\
\hline $\begin{array}{l}\text { Technological Content } \\
\text { Knowledge (TCK) }\end{array}$ & 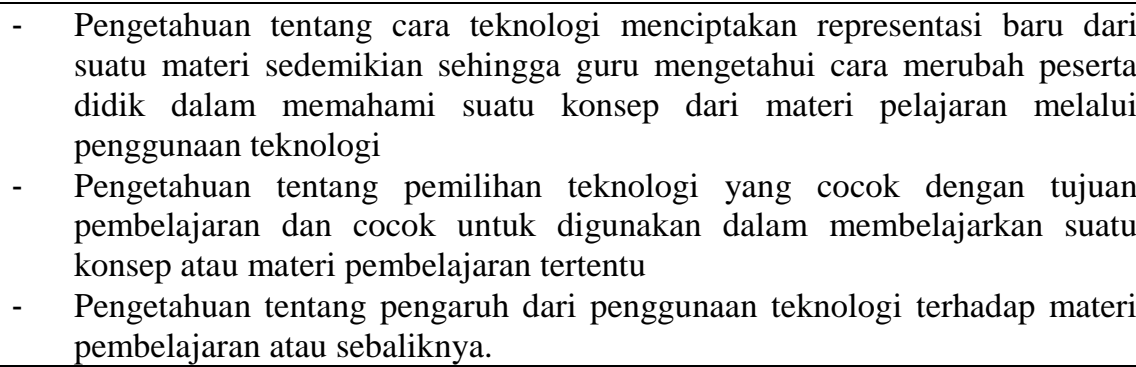 \\
\hline $\begin{array}{l}\text { Pedagogical Content } \\
\text { Knowledge (PCK) }\end{array}$ & $\begin{array}{l}\text { Pengetahuan terhadap cara memadukan antara materi pembelajaran dengan } \\
\text { pedagogik untuk mengembangkan proses pembelajaran yang lebih baik }\end{array}$ \\
\hline
\end{tabular}

Pengintegrasian TPACK dalam Pembelajaran Transformasi Geometri ... (Rafi \& Sabrina) 
Pengetahuan tentang penggunaan strategi pembelajaran dalam membelajarkan materi pelajaran yang berbeda

Pengetahuan terhadap pembelajaran, kurikulum, penilaian, dan pelaporan serta kaitan antara kurikulum, penilaian, dan pedagogik

\section{Pemanfaatan GeoGebra dalam Pembelajaran Transformasi Geometri SMA}

Penggunaan teknologi berupa software atau aplikasi matematika dalam pembelajaran matematika di abad 21 ini seperti suatu kebutuhan, terlebih apabila apabila materi atau konsep matematika yang sedang dipelajari atau diajarkan kepada peserta didik cukup sulit, abstrak dan perlu visualisasi untuk memudahkan dalam memahami konsep tersebut. Salah satu software yang dapat digunakan adalah GeoGebra. GeoGebra merupakan perangkat yang dapat digunakan untuk meng-integrasikan teknologi dalam pembelajaran matematika sekaligus dapat memotivasi peserta didik untuk mengeksplor matematika dan memberikan kesempatan peserta didik untuk dapat berpikir kritis, yang mana berpikir kritis merupakan inti dari konstruktivisme (Bhagat \& Chang, 2015). Lebih lanjut, menurut Hohenwarter \& Fuchs (2004), penggunaan GeoGebra dalam pembelajaran matematika di sekolah menengah adalah sebagai alat untuk: (a) mendemonstrasikan dan memvisualisasikan konsep matematika tertentu; (b) mengonstruksi objek atau konsep matematika; (c) menemukan suatu konsep matematika; dan (d) membantu guru dalam mempersiapkan materi pembelajaran, misalkan Lembar Kegiatan Peserta Didik (LKPD).

Salah satu materi matematika yang diajarkan di jenjang Sekolah Menengah Atas (SMA) adalah transformasi geometri, yang meliputi submateri translasi, rotasi, refleksi, dan dilatasi. Menurut Paradesa (2016), banyak peserta didik yang mengalami kesulitan pada bidang kajian geometri ruang yang mana kesulitan ini berkaitan erat dengan kemampuan visual-spatial thinking yang masih rendah. Rendahnya kemampuan visualspatial thinking ini dapat menjadikan peserta didik kesulitan dalam memahami keabstrakan geometri yang secara langsung juga memengaruhi pemahaman peserta didik terhadap konsep dan materi transformasi geometri. Lebih lanjut, menurut Idris (Seloraji \& Eu, 2017), beberapa faktor penyebab kesulitan peserta didik dalam mempelajari geometri adalah bahasa geometri, kemampuan visualisasi dan pengajaran yang tidak efektif. Salah satu cara yang dapat digunakan untuk mengembangkan kemampuan visual-spatial thinking atau kemampuan visualisasi tersebut adalah dengan memanfaatkan GeoGebra dalam pembelajaran transformasi geometri, sebab seperti yang telah di sebutkan sebelumnya, GeoGebra dapat digunakan sebagai alat untuk memvisualisasikan konsep matematika tertentu. Ada beberapa hal yang harus di-perhatikan dalam penggunaan GeoGebra tersebut, yaitu mengenai keefektifannya ketika digunakan dalam pembelajaran dan bagaimana guru mendesain proses dan materi pembelajaran yang konstruktif dan efektif dengan berbantuan GeoGebra.

\section{Pengintegrasian TPACK dalam Pembelajaran Transformasi Geometri SMA untuk Mengembangkan Profesionalitas Guru Matematika}

Penggunaan teknologi dalam pembelajaran matematika merupakan suatu keumuman di abad 21 ini. Menurut NCTM (2000), penggunaan teknologi dalam pembelajaran berpengaruh pada apa yang diajarkan dan kapan suatu materi pembelajaran muncul di dalam suatu kurikulum. Oleh karena itu, guru perlu memastikan bahwa penggunaan teknologi dalam pembelajaran tersebut efektif. Selain itu, guru seharusnya dapat menggunakan teknologi untuk meningkatkan kesempatan peserta didik dalam mengonstruk pengetahuannya sendiri dengan cara memilih atau membuat tugas matematis yang dapat mengambil keuntungan dari apa yang teknologi tersebut dapat lakukan secara baik dan 
efektif-menggambar, memvisualisasi, dan menghitung (NCTM, 2000). Lebih lanjut guru juga perlu memahami kapan menggunakan teknologi, bagaimana menggunakan teknologi dan dampak apa yang (mungkin) ditimbulkan dari penggunaan teknologi dalam pembelajaran. Terakhir, ketika memilih untuk menggunakan teknologi sebagai bagian dari pembelajaran, guru harus memahami unsur-unsur dan implikasi-implikasi dari penggunaan teknologi terkait dengan pengajaran, manajemen, konten (materi), pedadogik, dan teknologi itu sendiri (Guerrero, 2010). Untuk mewujudkan guru yang demikian, perlu dikembangkannya profesionalitas guru - terkait kompetensi pedagogik dan kompetensi profesional-berdasarkan kerangka TPACK.

Salah satu cara yang dapat digunakan untuk mengembangkan profesional-itas guru adalah dengan pengadaan workshop pengintegrasian TPACK dalam pembelajaran transformasi geometri SMA dengan menggunakan GeoGebra. Model workshop yang dibahas dalam artikel ini didasarkan pada model workshop yang digunakan oleh Bhagat, Chang, \& Huang (2017) dalam meneliti tentang pengintegrasian GeoGebra dengan TPACK dalam usaha untuk mengembangkan profesionalitas calon guru matematika yang mana model workshop tersebut dapat mengembangkan profesionalitas calon guru matematiaka. Adapun model workshop yang ditawarkan melalui artikel ini disajikan dalam Tabel 3 berikut.

Tabel 3. Model Workshop Pengintegrasian TPACK dalam Pembelajaran Transformasi Geometri SMA untuk Mengembangkan Profesionalitas Guru Matematika

\begin{tabular}{lc}
\hline \multicolumn{1}{c}{ Materi Workshop } & $\begin{array}{c}\text { Komponen TPACK } \\
\text { yang Dikembangkan }\end{array}$ \\
\hline Pemaparan materi mengenai teori-teori dan prinsip TPACK & TPACK \\
\hline Pengenalan terhadap GeoGebra (secara umum) & TK \\
\hline $\begin{array}{l}\text { Pengenalan terhadap tampilan antarmuka dan menu-menu dalam GeoGebra } \\
\text { terkait dengan transformasi geometri: Reflect about Line, Reflect about Point, }\end{array}$ & TCK \\
Reflect about Circle, Rotate around Point, Translate by Vector, dan Dilate from \\
Point & \\
\hline $\begin{array}{l}\text { Pendesainan suatu konsep transformasi geometri dengan meng-gunakan } \\
\text { GeoGebra }\end{array}$ & TCK \\
\hline $\begin{array}{l}\text { Pendesainan suatu masalahan transformasi geometri yang dinamis dan interaktif } \\
\text { menggunakan GeoGebra }\end{array}$ & TCK \\
\hline $\begin{array}{l}\text { Pendesainan lembar kerja peserta didik (LKPD) yang konstruktif pada materi } \\
\text { transformasi geometri dengan menggunakan GeoGebra (lihat Lampiran) }\end{array}$ & TPACK \\
\hline $\begin{array}{l}\text { Pemaparan dan simulasi pembelajaran transformasi geometri dengan GeoGebra } \\
\text { berdasarkan kerangka TPACK (misal: discovery learning atau inquiry based } \\
\text { learning) }\end{array}$ & TPACK \\
\hline $\begin{array}{l}\text { Pemaparan materi tentang cara penilaian peserta didik pada pembelajaran } \\
\text { transformasi geometri SMA yang memanfaatkan GeoGebra (misal: penilaian } \\
\text { autentik atau portofolio) }\end{array}$ & TPACK \\
\hline
\end{tabular}

Profesionalitas guru yang setidaknya tercermin dari kompetensi pedagogik dan kompetensi profesional dapat dikembangkan melalui model workshop yang disajikan pada Tabel 3. Materi yang disajikan dapat memfasilitasi berkembanya dua kompetensi tersebut karena mayoritas materi yang disajikan pada workshop mencakup pengembangan TPACK.

\section{SIMPULAN}

Berdasarkan hasil kajian pustaka yang telah dilakukan, pengintegrasian TPACK dapat mengembangkan profesionalitas guru matematika melalui kegiatan workshop penggunaan GeoGebra dalam pembelajaran transformasi geometri SMA. Akan tetapi, pembahasan 
mengenai pengintegrasian TPACK dalam pembelajaran transformasi geometri ini masihlah berupa hasil kajian. Oleh karena itu, perlu dikaji lebih mendalam dan perlu diteliti apakah workshop pengintegrasian TPACK dan penggunaan Geogebra dalam pembelajaran transformasi geometri SMA memang dapat mengembangkan profesionalitas guru matematika. Lebih lanjut, perlu juga dikaji mengenai model kegiatan workshop pengintegrasian TPACK dan penggunaan Geogebra dalam pembelajaran matematika yang seperti apa yang secara maksimal dapat mengembangkan profesionalitas guru SMA.

\section{DAFTAR PUSTAKA}

Ariani, D. N. (2015). Penelitian hubungan antara technological pedagogical content knowledge dengan technology integration self efficacy guru matematika di sekolah dasar. MUALLIMUNA: Jurnal Madrasah Ibtidaiyah, 1(1), 79-91.

Bhagat, K. K., \& Chang, C. (2015). Incorporating GeoGebra into Geometry learning-A lesson from India. Eurasia Journal of Mathematics, Science \& Technology Education, 11(1), 77-86.

Bhagat, K. K., Chang, C., \& Huang, R. (2017). Integrating GeoGebra with TPACK in improving Pre-service Mathematics Teachers' Professional Development. In IEEE 17th International Conference on Advanced Learning Technologies Integrating (pp. 313-314).

Doering, A., Veletsianos, G., Scharber, C., \& Miller, C. (2009). Using the Technological, Pedagogical, and Content Knowledge Framework to Design Online Learning Environments and Professional Development. Journal of Educational Computing Research, 41(3), 319-346.

Guerrero, S. (2010). Technological Pedagogical Content Knowledge in the Mathematics Classroom. Journal of Digital Learning in Teacher Education, 26(4), 132-139.

Hohenwarter, M., \& Fuchs, K. (2004). Combination of dynamic geometry, algebra and calculus in the software system GeoGebra. Retrieved from https://archive.geogebra.org/static/publications/pecs_2004.pdf

Koehler, M. J., Mishra, P., \& Cain, W. (2013). What Is Technological Pedagogical Content Knowledge (TPACK)? Journal of Education, 193(3), 13-19.

Listiawan, T., \& Baskoro, W. W. (2015). Analisis Technological Content Knowledge (TCK) Calon Guru Matematika Dalam Menggunakan Perangkat Lunak Geometri Dinamis, 827-834.

Marsigit. (2008). Pengembangan Kompetensi Guru Matematika melalui Model-model Pembelajaran, Lesson Study dan PTK melalui Peningkatan Peran MGMP. Retrieved February 24, 2018, from http://staff.uny.ac.id/system/files/pengabdian/marsigit-dr$\mathrm{ma}$ /pengambangan-kompetensi-guru-matematika-melalui-model-model-

pembelajaranlessonstudy-dan-ptk-melalui-.pdf

Mishra, P., \& Koehler, M. J. (2006). Technological Pedagogical Content Knowledge: A Framework for Teacher Knowledge. Teachers College Record, 108(6), 1017-1054.

Mishra, P., \& Koehler, M. J. (2008). Introducing Technological Pedagogical Content Knowledge. Paper Presented at the Annual Meeting of the American Educational Research Association, 1-16.

NCTM. (2000). Principles and Standards for School Mathematics. Reston, VA: The National Council of Teacher of Mathematics, Inc. Retrieved from http://webapp1.dlib.indiana.edu/virtual_disk_library/index.cgi/4273355/FID3542/D OCS/ENC2280/28023310.HTM 
Paradesa, R. (2016). Pengembangan Bahan Ajar Geometri Transformasi Berbasis Visual. Jurnal Pendidikan Matematika JPM RAFA, 2(1), 56-84.

Peraturan Menteri Pendidikan dan Kebudayaan Republik Indonesia Nomor 57 Tahun 2012 tentang Uji Kompetensi Guru.

Purnama, E. (2015). Ada apa dengan Diklat Pasca UKG? Retrieved from https://www.kompasiana.com/eddiepurnama/ada-apa-dengan-diklat-pascaukg_556c228d307a6137058b4568

Ridla, M. (2008). Profesionalitas Guru Pendidikan Agama Islam dalam Proses Pembelajaran. Tadris, 3(1), 30-44.

Schmidt, D. A., Baran, E., Thompson, A. D., Mishra, P., Koehler, M. J., \& Shin, T. S. (2009). Technological Pedagogical Content Knowledge (TPACK): The Development and Validation of an Assessment Instrument for Preservice Teachers. Journal of Research on Technology in Education, 42(2), 123-149.

Seloraji, P., \& Eu, L. K. (2017). Students' Performance in Geometrical Reflection Using GeoGebra. Malaysian Online Journal of Educational Technology, 5(1), 65-77.

Sururi. (2002). Pengembangan Visi Sekolah: Meningkatkan Profesionalisasi Guru dan Kepala Sekolah. Makalah Disampaikan Pada Kegiatan P2M Tanggal 19 Oktober 2002. Retrieved from http://file.upi.edu/Direktori/FIP/JUR._ADMINISTRASI_PENDIDIKAN/197011091 998021-

SURURI/mklh_abmas_PROFSIONALISASI_TENAGA_KEPENDIDIKAN.pdf Undang-undang Republik Indonesia Nomor 14 Tahun 2005 tentang Guru dan Dosen. 


\title{
Integrating TPACK in Geometry Transformation Learning in Senior High School to Develop Mathematics Teachers' Professionality
}

\author{
Ibnu Rafi * \\ Department of Mathematics Education, Universitas Negeri Yogyakarta, Yogyakarta, Indonesia \\ Corresponding Author, ibnurafi789@gmail.com \\ Nurrita Sabrina \\ Department of Mathematics Education, Universitas Negeri Yogyakarta, Yogyakarta, Indonesia \\ momo.aina25@gmail.com
}

\begin{abstract}
This article discusses the way of integrating the Technological, Pedagogical and Content Knowledge (TPACK) framework in geometry transformation learning at senior high school to improve the professionality of mathematics teachers. This article is a result from many sources of study such as journal articles, statutes and credible websites whose themes are TPACK, teacher competency test/Uji Kompetensi Guru (UKG), professionality of the teacher, and the utilization of GeoGebra in the learning activity. This article is motivated by the average of UKG in mathematics field which indicates that mathematics teahers', profesionality should be developed, especially in terms of pedagogical and profesional competency. One of the frameworks that may facilitate mathematics teachers to develop their pedegogical and profesional competency is Technological, Pedagogical and Content Knowledge (TPACK). Through TPACK, mathematics teachers are expected to be able to integrate technology within mathematics learning, especially the abstract one, such as transformation geometry learning. According to the literature review that has been conducted, integrating TPACK can develop the professionality of mathematics teacher through the workshop of integrating GeoGebra in geometry transformation learning at senior high school.
\end{abstract}

Keywords: Geometry transformation, teacher professionality, TPACK, workshop of integrating GeoGebra

Received August $29^{\text {th }}, 2018$

Revised November $18^{\text {th }}, 2018$

Accepted November $26^{\text {th }}, 2018$ 